\title{
Positive correlation between the number of bacteria in soybean tempeh with the bioactivity of its extract against enterotoxigenic Escherichia coli (ETEC) adhesion to eukaryotic cells
}

\author{
"Pramudito, T.E., Florencia, G., Gunawan, M.R., Pratiwi, M.P. and Yogiara, Y. \\ Faculty of Biotechnology, Atma Jaya Catholic University of Indonesia, Cisauk, Tangerang, Banten 15345, \\ Indonesia
}

\author{
Article history: \\ Received: 16 February 2021 \\ Received in revised form: 18 \\ March 2021 \\ Accepted: 22 May 2021 \\ Available Online: 5 \\ December 2021 \\ Keywords: \\ Tempeh, \\ Diarrhea, \\ Enterotoxigenic Escherichia \\ coli (ETEC), \\ Bacteria, \\ Yeast agglutination assay, \\ Anti-adhesion bioactivity
}

\begin{abstract}
Bioactive oligosaccharides from soybean tempeh can inhibit the adhesion of enterotoxigenic Escherichia coli (ETEC) to intestinal cells, thus reducing the severity of ETEC-mediated diarrhea. Bacteria are also present in tempeh but there has yet been any report regarding their effect on the anti-adhesion bioactivity of tempeh. In this research, the bacterial number in tempeh was quantified and the anti-adhesion bioactivity of tempeh extract was determined using yeast agglutination assay. Statistical analysis showed a moderately $(R=0.69)$ significant positive correlation $(P<0.01)$ between the number of bacteria in tempeh and the anti-adhesion bioactivity of its extract. In conclusion, tempeh that contains more bacteria is more effective in inhibiting ETEC adhesion to eukaryotic cells. This could be due to a symbiosis between Rhizopus and bacteria in breaking down soy matrix polysaccharides to release bioactive oligosaccharides.
\end{abstract}

DOI:

https://doi.org/10.26656/fr.2017.5(6).110

\section{Introduction}

Enterotoxigenic Escherichia coli (ETEC) is associated with two types of diarrhoea: weanling diarrhoea among children and traveller's diarrhoea (Qadri et al., 2005). The former is considered a major problem in developing countries such as Indonesia where food hygiene is lacking. The disease is triggered by the adhesion of ETEC to the intestinal epithelium, which leads to the colonization and infection of the intestinal tract. ETEC adhesion is also required for enterotoxins production that leads to an increase in water secretion and a decrease in nutrient absorption by enterocytes (Nagy and Fekete, 2005).

Tempeh is a traditional Javanese fermented food made from the fermentation of soybean by moulds such as Rhizopus oligosporus. The major steps of tempeh production include soybean boiling, soaking, dehulling, inoculation with starter and incubation to allow for mould growth and fermentation. This fermentation process contributes to texture and flavour development and inactivates antinutritional components in soybeans (Nout and Kiers, 2005). Moreover, it has been reported that tempeh could decrease diarrheal severity compared to unfermented toasted soybeans (Kiers et al., 2007). This bioactivity arises from oligosaccharide molecules
$>30 \mathrm{kDa}$ in molecular mass that might be released from the degradation of soy matrix polysaccharides by microorganisms. These bioactive oligosaccharides are known to contain arabinose residue and are stable in high temperatures (Roubos-van den Hil, Schols, Nout et al., 2010).

Bacteria are also present in tempeh and can determine some of the product's characteristics. The bacterial population in tempeh is dominated by Firmicutes, especially lactic acid bacteria (LAB), with Proteobacteria as the sub-dominant phylum (Radita et al., 2018). Radita et al. (2017) reported that the bacterial population in tempeh, in particular LAB, increased significantly over the course of soybean soaking. During soaking, the $\mathrm{pH}$ of soybeans and their soaking water decrease due to the production of organic acids by LAB (Nout et al., 1987). Such low $\mathrm{pH}$ helps to inhibit the growth of spoilage microorganisms. Bacteria also influence the nutritional and sensory properties of tempeh such as through the production of vitamin B12 by Klebsiella pneumoniae and the formation of bitter flavour by Escherichia coli (Keuth and Bisping, 1994; Barus et al., 2008; Ayu et al., 2014; A'yun et al., 2015). The bacterial population in tempeh could also act as an immunostimulant which can help to protect against 
pathogen infection (Soka et al., 2014).

Despite the potential of tempeh as a functional food with anti-diarrheal activity, to date, there are no reports regarding the effect of bacterial number in tempeh on its bioactivity. Most findings were based on tempeh fermented in laboratory conditions, which did not consider the presence of these bacterial populations. Considering that the bioactive compound content in tempeh might arise from the degradation of soy polysaccharides, it is possible that these bacteria might play an important role as well. Therefore, this research is aimed to study the correlation between the bacterial number and anti-adhesion bioactivity in tempeh using the yeast agglutination assay, in which the yeast Saccharomyces cerevisiae acted as a substitute to epithelial cells to model ETEC adhesion to eukaryotic cells. Findings in this research will shed light on the ideal tempeh microbial profile that can inhibit ETEC infection, in search of an accessible prebiotic product against ETEC-induced diarrhoea.

\section{Materials and methods}

\subsection{Materials}

Commercial tempeh samples were from five different producers in Bogor (EMP and RTI), Jakarta (JKT) and Surabaya (HNA). All samples were stored and transported in an icebox prior to analysis. In the case of HNA, tempeh was kept at room temperature for 48 $72 \mathrm{hrs}$ until fungal mycelium was fully formed before it was stored in an icebox. Table 1 shows a summary of various production methods involved for each commercial tempeh. All tempeh samples were made with the same type of yellow-seeded elongated soybean. Starters used for lab-made tempeh were the commercial starters Raprima (RP; PT. Aneka Fermentasi Industri, Bandung, Indonesia), Cap Jago (JG; UD. Jaya Mulya, Kediri, Indonesia) and cassava-based onggok (byproduct of tapioca production) starter (OG; acquired from a traditional producer in Cisauk, Banten, Indonesia). Saccharomyces cerevisiae and ETEC cultures were obtained from the Faculty of Biotechnology, Atma Jaya Catholic University of Indonesia (Cisauk, Indonesia). D-(+)-mannose was purchased from Sigma Aldrich (Darmstadt, Germany).

\subsection{Tempeh preparation}

Lab-made tempeh was prepared based on a method described by Kustyawati (2009) with modifications. Full -fat yellow-seeded elongated soybeans were used for tempeh fermentation and purchased from Pasar Modern Intermoda BSD (Tangerang, West Java). The soybeans were soaked overnight in distilled water at room temperature and boiled and dehulled. After the soybeans were cooled and dried, they were mixed thoroughly with a tempeh starter $(0.2 \%(\mathrm{w} / \mathrm{w})$ of soybeans). The mixture was packed in a perforated plastic bag and incubated at $30^{\circ} \mathrm{C}$ for $48 \mathrm{hrs}$. The resulting tempeh was immediately used for analysis.

\subsection{Bacterial enumeration}

Bacteria were isolated from the inner part of tempeh, in which the outer surface of tempeh samples was sliced off, and the remaining samples were diced. Diced tempeh $(10 \mathrm{~g})$ was transferred into a plastic bag and 90 $\mathrm{mL}$ phosphate-buffered saline (PBS) pH 7.4 (Ambion, USA) was added to the sample. The mixture was homogenized using a stomacher for $1 \mathrm{~min}$. The bacterial suspension was collected in a centrifuge tube to be immediately used for bacterial enumeration. Serial dilutions of bacterial suspensions up to $10^{-8}$ followed by plate count agar (Oxoid, USA) were poured into a petri dish and incubated at $30^{\circ} \mathrm{C}$ for $48 \mathrm{hrs}$. The measurement was replicated four times for each dilution factor and the bacterial number was expressed as log CFU/g tempeh.

\subsection{Extraction of bioactive oligosaccharides}

Bioactive oligosaccharides were extracted from tempeh using a method as described by Roubos-van den Hil, Schols, Nout et al. (2010) with modifications. Commercial and lab-made tempeh were lyophilized for $96 \mathrm{hrs}$ and ground into a fine powder. The powder ( $75 \mathrm{~g}$ ) was stirred into $1 \mathrm{~L}$ distilled water for $1 \mathrm{hr}$ at room temperature. The $\mathrm{pH}$ of the suspension was adjusted to 8.0 with $\mathrm{NaOH} 2 \mathrm{M}$ every 30 mins. The suspension was then centrifuged $\left(30\right.$ mins, $\left.10000 \times g, 20^{\circ} \mathrm{C}\right)$ and filtered to obtain soluble tempeh crude extract, which was

Table 1. Different production methods for commercial and lab-made tempeh samples

\begin{tabular}{cccccccc}
\hline Sample & Source & Cooking & Dehulling & Starter mixing & Packaging & Environmental hygiene & Water source \\
\hline EMP & Bogor & One stage & Mechanic & Manual & Banana leaf & Non-aseptic & Groundwater \\
RTI & Bogor & Two stages & Mechanic & Mechanic & Plastic & Aseptic & PAM $^{1}$ \\
JKT & Jakarta & Two stages & Mechanic & Manual & Plastic & Semi-aseptic & PAM \\
HNA $^{2}$ & Surabaya & Two stages & Mechanic & Mechanic & Plastic & Aseptic & PAM \\
Lab-made $^{3}$ & Cisauk & One stage & Manual & Manual & Plastic & Aseptic & PAM \\
\hline
\end{tabular}

\footnotetext{
${ }^{1}$ Water provided by the national water utility service.

${ }^{2}$ HNA was distributed to the consumers in the state of mid-fermentation to ensure tempeh freshness.

${ }^{3}$ Made with three different commercial starters.
} 
further lyophilized for $96 \mathrm{hrs}$ and stored at $4^{\circ} \mathrm{C}$ before analysis.

\subsection{Determining the anti-adhesion bioactivity of samples}

The capability of tempeh extract to inhibit ETEC adhesion to eukaryotic cells was analysed using yeast agglutination assay as described by Mirelman et al. (1980) with modifications. Tempeh extract $(2 \%(\mathrm{w} / \mathrm{v}))$ was suspended in PBS pH 7.4 and vortexed for 30 mins to ensure optimum homogenization. The suspension was centrifuged at $10000 \times g$ for 10 mins and the supernatant was collected. Mannose 2\% (w/v) was used as positive control.

Saccharomyces cerevisiae cells were grown on potato dextrose broth (HiMedia, India) with shaking overnight at $30^{\circ} \mathrm{C}$. ETEC was grown on Luria Bertani broth (HiMedia) without shaking at $37^{\circ} \mathrm{C}$ for $20 \mathrm{hrs}$. Both yeast and ETEC cells were pelleted by centrifugation at $3000 \times g$ for 5 mins at $4^{\circ} \mathrm{C}$ and suspended in an equal volume of PBS pH 7.4. The cells were washed twice in PBS pH 7.4 and cell densities of yeast and ETEC suspensions were adjusted to $\mathrm{OD}_{600}$ of 1.0 and 0.5 , respectively. Aliquots of the tempeh extract $(10 \mu \mathrm{L})$ were mixed with ETEC suspension $(10 \mu \mathrm{L})$ in a 96-wells microtiter plate and incubated at room temperature with orbital shaking at $300 \mathrm{rpm}$ for $10 \mathrm{mins}$. Yeast suspension $(10 \mu \mathrm{L})$ was later added into the mixture and incubated for 30 mins at $300 \mathrm{rpm}$. A mixture of an equal volume of yeast and ETEC suspension in PBS pH 7.4 was used as a negative control. The suspension was then transferred onto concave object glass and carefully covered with cover glass. Cell agglutinates were observed using a light microscope (Nikon Eclipse E100; Tokyo, Japan) at 100× magnification. The program DinoCapture 2.0 (Dino-Lite, Torrance, CA, USA) was used for the enumeration of yeast agglutinates. The number of agglutinates was determined as the sum of agglutinates observed from seven location points in the object-glass and the measurement was repeated six times. Anti-adhesion bioactivity of samples against ETEC adhesion to yeast cells was calculated with the following formula:

$$
\% \text { adhesion inhibition }=100 \%-\frac{\overline{\mathrm{X}} \mathrm{N}}{\overline{\mathrm{X}} \mathrm{C}} \times 100 \%
$$

Where $\overline{\mathrm{X}} \mathrm{N}$ is the average number of agglutinates in sample and $\bar{X} \mathrm{C}$ is the average number of agglutinates in negative control.

\subsection{Statistical analysis}

SPSS Statistics (IBM Corporation, Armonk, NY, USA) was used for statistical analysis of all data acquired from this experiment. The anti-adhesion bioactivity of tempeh extract was compared to the positive control (mannose 2\% (w/v)) using one-way ANOVA and two groups were considered statistically different at $P<0.05$. The correlation between bacterial number in tempeh based on TPC and anti-adhesion bioactivity of tempeh extract was determined by calculating $P$-value and Pearson correlation coefficient ( $R$-value) of the two variables. Correlation was considered significant at $P<0.01$.

\section{Results}

\subsection{Bacterial number in tempeh samples}

TPC showed that the bacterial number in tempeh samples among commercial samples was more varied compared to that among lab-made tempeh (Figure 1). EMP contained the highest bacterial number among commercial samples at $9.24 \pm 0.004 \mathrm{Log} \mathrm{CFU} / \mathrm{g}$, while RTI contained the least number of bacteria compared to the other samples at $6.42 \pm 0.029 \mathrm{Log} \mathrm{CFU} / \mathrm{g}$. The bacterial number in tempeh made using a two-stage cooking process (RTI, JKT and HNA) was lower than in tempeh made with a one-stage cooking process (EMP and lab-made samples). The number of bacteria in labmade tempeh (OG, RP and JG) was similar to that in EMP and higher compared to other commercial tempeh. The abundance of bacteria in lab-made tempeh could be due to the production method, in which one-stage cooking was employed and the soybeans were dehulled manually. Lab-made tempeh with the highest and lowest bacterial number was JG $(9.61 \pm 0.006 \log \mathrm{CFU} / \mathrm{g})$ and OG $(9.23 \pm 0.027 \log \mathrm{CFU} / \mathrm{g})$, respectively. All lab-made tempeh was prepared using the identical method, except for the type of starter culture used, thus resulting in samples with a similar level of bacteria. In general, the

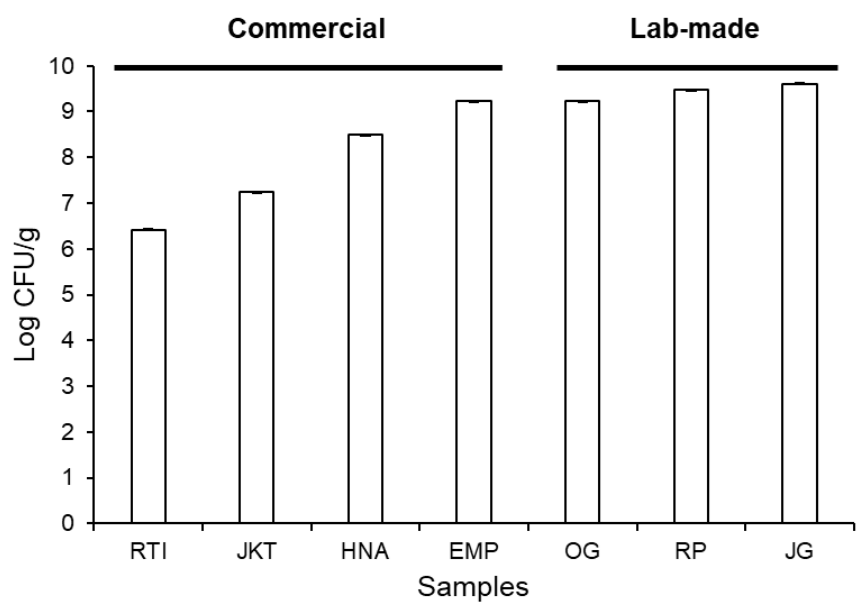

Figure 1. The bacterial enumeration in commercial (RTI, JKT, HNA and EMP) and lab-made (OG, RP and JG) tempeh samples based on total plate count. Bacterial colonies were grown on plate count agar (Oxoid) and counted after $48 \mathrm{hrs}$ incubation at $30 \mathrm{oC}$. Bacterial count is expressed at $\log \mathrm{CFU} / \mathrm{g}$ total weight of sample based on four replicates. Error bars represent standard errors. 
samples were found to be suitable for correlation study as the set contained samples with both varying and similar degrees of bacterial number.

\subsection{Anti-adhesion bioactivity of tempeh extract}

The anti-adhesion bioactivity of tempeh extract against ETEC was measured using yeast agglutination assay. In the presence of ETEC, yeast cells formed agglutinates due to the adhesion of ETEC cells to the surface of the yeast cell wall. Carbohydrates such as mannose bind to ETEC fimbriae thus inhibiting the formation of cell agglutinates (Figure 2A). In this research, the number of cells agglutinates quantified were observed at $100 \times$ magnification to determine the anti-adhesion bioactivity of the sample. The antiadhesion bioactivity of tempeh extract at $2 \%(\mathrm{w} / \mathrm{v})$ was expressed as percent adhesion inhibition by comparing the number of agglutinates in yeast and ETEC suspension added with tempeh extract, to suspension without tempeh extract addition. Mannose $2 \%(\mathrm{w} / \mathrm{v})$ was used as positive control and showed $81.73 \pm 2.57 \%$ adhesion inhibition. In general, extracts from lab-made tempeh showed higher adhesion inhibition against ETEC than commercial samples (Figure 2B). All samples showed significantly lower bioactivity $(P<0.05)$ than mannose at the same concentration, except for OG and

A
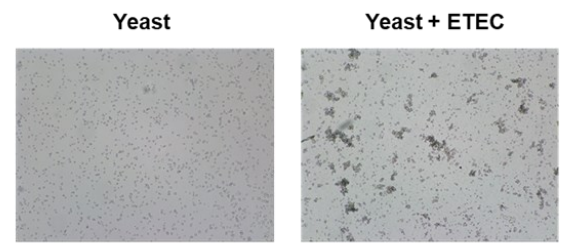

Yeast + ETEC + Mannose 2\%

B

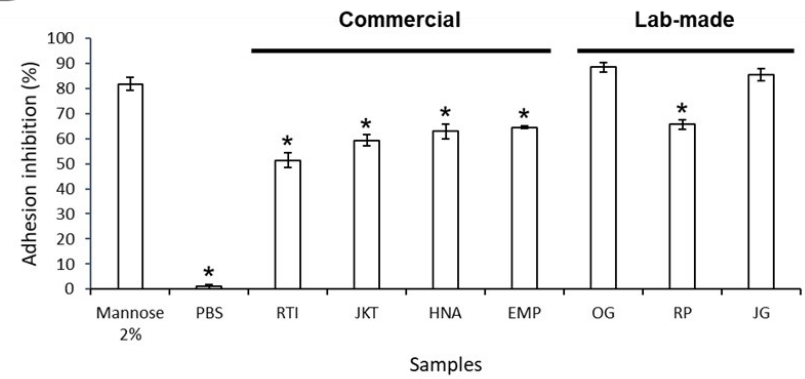

Figure 2. Yeast agglutination assay for the determination of anti-adhesion bioactivity against ETEC. A) Microscopic observation of $S$. cerevisiae cells at $100 \times$ magnification. From left to right: $S$. cerevisiae cells with no treatment, in the presence of ETEC and the presence of ETEC and 2\% (w/v) mannose. B) Anti-adhesion bioactivity of $2 \%(\mathrm{w} / \mathrm{v})$ tempeh extract against ETEC adhesion to $S$. cerevisiae. Mannose (2\% $(\mathrm{w} / \mathrm{v}))$ was used as a positive control and phosphate buffer saline (PBS) $\mathrm{pH} 7.4$ was used as a negative control. Bars represent the mean of percentage adhesion inhibition based on six replicates. Error bars represent standard errors. Bars with asterisks notation indicate significant difference $(\mathrm{P}<0.05)$ between tempeh treatment and the mannose control.
JG. Among commercial tempeh, EMP extract had the highest bioactivity at $64.53 \pm 0.67 \%$ inhibition. RTI extract showed the lowest inhibition against ETEC adhesion at $51.37 \pm 2.82 \%$. The adhesion inhibition bioactivities of lab-made JG and OG were not significantly different compared to mannose at $85.36 \pm 2.37$ and $88.41 \pm 1.88 \%$, respectively. RP was the only lab-made tempeh that showed a significantly lower adhesion inhibition level compared to mannose at $65.59 \pm 1.99 \%$.

\subsection{Bacterial number in tempeh positively correlated with anti-adhesion bioactivity of its extract}

Statistical analysis showed a significant correlation between the bacterial number in tempeh and its adhesion inhibition bioactivity $(P<0.01)$. As the number of bacteria in tempeh increased, the anti-adhesion effect was also higher (Figure 3). Furthermore, both variables had a Pearson correlation coefficient ( $R$-value) of 0.69 , indicating a strong positive relationship between them.

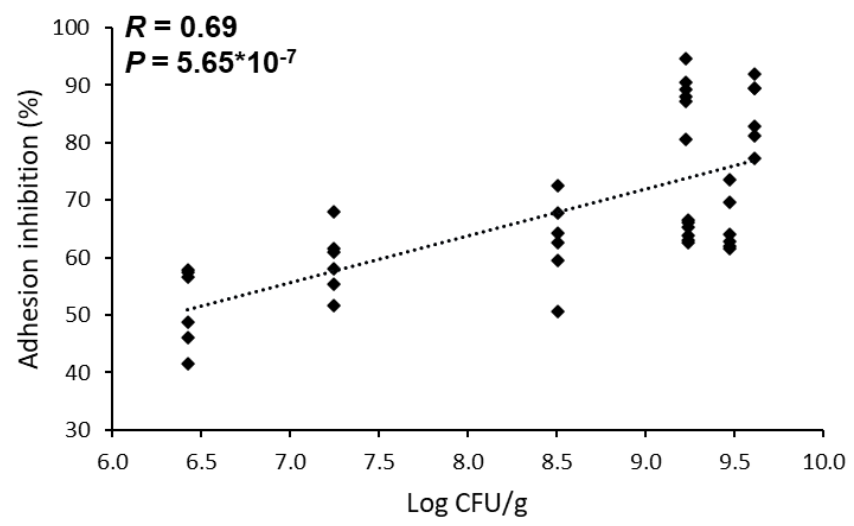

Figure 3. Correlation between anti-adhesion bioactivity of tempeh extract at $2 \%(\mathrm{w} / \mathrm{v})$ (expressed as $\%$ adhesion inhibition) and bacterial number in tempeh based on total plate count (expressed as Log CFU/g tempeh). Regression line is represented by a dotted line. Statistical analysis with SPSS Statistics (IBM Corporation) gave the $P$-value of $5.65 \times 10^{-7}$ and $R$-value of 0.69 , indicating a significant positive moderate correlation $(P<0.01)$.

\section{Discussion}

In this research, seven tempeh samples that consisted of four commercial and three lab-made tempeh were analysed. The commercial tempeh was obtained from four different producers employing various production methods (Table 1). This resulted in a highly variable bacterial number among commercial samples (Figure 1). Samples that were produced with the two-stage cooking process (RTI, JKT and HNA), contained a lower number of bacteria compared to EMP. The two-stage cooking process is known to decrease the bacterial number in the product compared to one-stage cooking (Mulyowidarso et al., 1989). RTI was also produced with a shorter 
soaking time compared to other commercial tempeh (Muzdalifah et al., 2017), which might also contribute to the low bacterial number in the product. Mulyowidarso et al. (1989) reported that the number of bacteria in soybean peaked after $24 \mathrm{hrs}$ of soaking thus shorter soaking time could significantly impact the number of bacteria in RTI. In the two-stage cooking process, soybeans were cooked before and after the soaking step (Barus et al., 2008; Efriwati et al., 2013). EMP and labmade tempeh, on the other hand, were prepared using a one-stage cooking process. It should be noted that the two-stage cooking process is still an uncommon practice in Indonesia with only one in five producers practising the method (Barus et al., 2008).

Similar to RTI, HNA was produced in a hygienic indoor environment, yet the number of bacteria in HNA was the second-highest among commercial samples. This could be related to how this tempeh was distributed, in which it was sold to consumers even before the fermentation process has been completed to ensure product freshness. Such an approach might favour bacterial growth as Rhizopus might grow slower due to less ideal fermentation conditions during distribution. It has previously been reported that slower fungal growth during tempeh fermentation led to an increase in bacterial count (Mulyowidarso et al., 1990). It should also be noted that there were contradictory findings regarding the effect of the cooking method on specific bacterial populations, i.e. LAB. Efriwati et al. (2013) reported a higher $\mathrm{LAB}$ number in tempeh made with the one-stage cooking process, while in contrast, Nurdini et al. (2015) reported that the LAB population was higher in tempeh made with two-stage cooking. This indicated that the bacterial population in tempeh could be very dynamic and incrementally influenced by various small parameters (Radita et al., 2018). Many conditions tend to be difficult to control, resulting in a product with a different bacterial profile from time to time.

In the case of EMP, soybeans were cooked only once before soaking. The high bacterial number in EMP has previously been reported and could be due to bacterial contamination after cooking and before the addition of tempeh starter (Barus et al., 2008; Seumahu et al., 2013; Radita et al., 2017; Radita et al., 2018). EMP was produced traditionally in an open-aired environment and the soybean soaking process was done using groundwater (Seumahu et al., 2013). Other samples in this experiment were made using soybeans soaked in fresh water provided by the Indonesian water utility service.

The high bacterial number in lab-made tempeh could be due to the growth of endogenous bacteria in soybeans.
For lab-made tempeh, soybeans were cooked once after the soaking process, a step that was reported to decrease only an insignificant number from the plethora of bacteria that grew during the soaking process (Mulyowidarso et al., 1989). Compared to commercial samples, the bacterial number in lab-made samples was relatively similar to one another. All three lab-made tempeh were produced with identical methods, with the type of starter used being the only variable factor. The lack of variation in bacterial number was in accordance with a previous report that showed that starter type did not significantly influence the bacterial profile in tempeh, as opposed to other parameters such as the soaking process (Radita et al., 2017).

The anti-adhesion bioactivity of tempeh extracts tended to be lower than that of mannose at the same concentration, except for OG and JG (Figure 2B). Both OG and JG showed anti-adhesion bioactivity that was not significantly different from mannose. The bioactivity of OG and JG was also $20 \%$ higher compared to RP, another lab-made sample. RP and JG were made using commercial starters, namely Raprima and Cap Jago, respectively. In Indonesia, Raprima is a commercial tempeh starter that is commonly used for tempeh production in West and Central Java (Radita et al., 2017). Cap Jago is another commercial starter which uses is limited to East Java. The slow rate of mycelium formation has been reported in tempeh produced with Cap Jago starter, resulting in tempeh with a less cohesive structure (Amaliyah et al., 2018). The slow rate of fungal growth might also allow for higher bacterial activity, especially during the early stage of the fermentation, as bacteria would have more time to utilize the nutrition in soybeans before having to compete with fully grown mould. OG was made using cassava-based onggok starter. Onggok refers to a cassava by-product from tapioca production (Radita et al., 2017). To make onggok starter, cassava is pressed into a cake, warmed up and used as a growth medium for Rhizopus before it is dried and ground into powder (Owens, 2014; Radita et al., 2017). The use of onggok--based starters is often limited to specific producers only, and each producer may have different production methods. In addition, the microbial profile in onggok is richer and more diverse as the starter is often produced using the uncontrolled traditional method (Radita et al., 2017). During onggok production, the cassava cake was not cooked and it was treated with warm water, which would an ideal environment for bacterial growth and metabolism (Owens, 2014; Tamam et al., 2019). This might lead to the presence of more active bacteria in the starter, which might account for higher bioactive oligosaccharide content in tempeh.

This research showed a significant positive 
correlation between the number of bacteria in tempeh and the anti-adhesion bioactivity of tempeh extract against ETEC. This finding could provide a new paradigm for the development of tempeh as a functional product. Roubos-van den Hil, Schols, Nout et al. (2010) reported that the anti-adhesion bioactivity in tempeh was due to the presence of oligosaccharides derived from the breakdown of soy matrix polysaccharides by Rhizopus. The presence of arabinose residues might play an important role in determining the anti-adhesion bioactivity of the product. Thus far, there has yet been any report that considered the effect of bacterial number in tempeh on its anti-adhesion bioactivity. Roubos-van den Hil, Nout, van der Meulen et al. (2010) showed that the bacterial fermentation of soybean, such as by Bacillus spp. increased its bioactivity. However, the report did not explore the possibility of bacterial role on bioactivity in real conditions for tempeh fermentation because the samples were made in a controlled laboratory environment. Our study is the first to show a tendency of anti-adhesion bioactivity increase following the increase of bacterial count in tempeh.

Some bacteria can produce polysaccharidedegrading enzymes such as exo-glucanase and $\beta$ glucosidase (Koeck et al., 2014; Asha et al., 2015). A higher bacterial count might allow for higher production of enzymes that are required to break down complex polysaccharides in tempeh into bioactive oligosaccharides. This increase could be due to mouldbacteria symbiosis during fermentation. It is possible that bacterial polysaccharide-degrading enzymes helped the initial breakdown of complex polysaccharides in the soybean matrix, therefore increasing their accessibility for the mould. The opposite might also take place where bacteria provide an extra step in the degradation of oligosaccharides released by moulds, thus increasing their bioactivity. Bacillus subtilis found in tempeh was reported to release arabinan-degrading enzymes (Kaji and Saheki, 1975; Raposo et al., 2004), and this might lead to an increase in arabinose-rich oligosaccharides. Kiers et al. (2002) reported that the growth of $B$. subtilis was not hindered by Rhizopus indicating that the modulation of $B$. subtilis might be a promising strategy to develop tempeh with higher anti-adhesion bioactivity.

Bacterial exo-polysaccharide (EPS) might also contribute to the increase of anti-adhesion bioactivity in samples with a high bacterial number. Bacterial EPS is accumulated by a wide range of bacterial groups, including LAB. EPS produced by Lactobacillus reuteri, for example, inhibited the agglutination of erythrocytes by ETEC (Wang et al., 2010). Lactobacillus reuteri had also been reported to be present in tempeh (Feng et al., 2005), although the EPS-producing capability of the specific strain found in tempeh has not been investigated. González-Ortiz et al. (2014) have reported the inhibition of ETEC adhesion onto porcine intestinal cells by EPS. Interestingly, said EPS consisted of glucose homopolysaccharides, indicating that a simple carbohydrate structure could also pose a bioactivity effect against ETEC adhesion. However, it has been demonstrated that tempeh fermented with Lactobacillus plantarum did not show anti-adhesion bioactivity against ETEC (Roubosvan den Hil, Nout, van der Meulen et al., 2010). Lactobacillus plantarum was shown to produce bioactive bacterial EPS (Dilna et al., 2015; Wang et al., 2018), yet there has been no report regarding its anti-adhesion bioactivity against ETEC. Further research needs to be done regarding the possible role of $\mathrm{LAB}$ in the bioactive property of tempeh.

\section{Conclusion}

Tempeh that contains more bacteria might be more effective in inhibiting ETEC adhesion to eukaryotic cells than tempeh that contains less bacteria. This correlation could be due to a symbiosis between Rhizopus and bacteria, in which one party might increase the accessibility of polysaccharides for the other, thus facilitating the production of bioactive oligosaccharides. Results from this research provide a new possibility for the exploration of the bacterial role in the bioactivity of tempeh. The next stage of this investigation should focus on the characterization of specific bacterial groups that play an important role in this correlation. Not only such development will lead to more information on the antiadhesion bioactivity of tempeh against ETEC, but it could also lead to the development of tempeh-based functional food products.

\section{Conflict of interest}

The authors declare no conflict of interest.

\section{Acknowledgments}

This work was funded by Science and Technology Research Grant from Indonesia Toray Science Foundation.

\section{References}

Amaliyah, F., Wisaniyasa, N.W. and Yusasrini, N.L.A. (2018). Pemanfaatan Bekatul Jagung dan Ragi Cap Jago untuk Pembuatan Ragi Tempe dan Karakteristik Tempe yang Dihasilkan. Jurnal Ilmiah Teknologi Pertanian Agrotechno, 2(2), 231-237. [In Bahasa Indonesia].

Asha, B.M., Pathma, J. and Sakthivel, N. (2015). 
Isolation and characterization of a novel thermostable $\beta$-glucosidase from Bacillus subtilis SU40. Applied Biochemistry and Microbiology, 51 (1), 21-26. https://doi.org/10.1134/ S0003683815010032

Ayu, E., Suwanto, A. and Barus, T. (2014). Klebsiella pneumoniae from Indonesian Tempeh were Genetically Different from that of Pathogenic Isolates. Microbiology Indonesia, 8(1), 2. https:// doi.org/10.5454/mi.8.1.2

A'yun, Q., Suwanto, A. and Barus, T. (2015). Genetic Profiles of Escherichia coli Isolated from Indonesian Tempeh Based on Enterobacterial Repetitive Intergenic Consensus- Polymerase Chain Reaction (ERIC-PCR). Microbiology Indonesia, 9(2), 2. https://doi.org/10.5454/mi.9.2.2

Barus, T., Suwanto, A., Wahyudi, A.T. and Wijaya, H. (2008). Role of Bacteria in Tempe Bitter Taste Formation: Microbiological and Molecular Biological Analysis Based on 16S rRNA Gene. Microbiology Indonesia, 2(1), 4. https:// doi.org/10.5454/mi.2.1.4

Dilna, S.V., Surya, H., Aswathy, R.G., Varsha, K.K., Sakthikumar, D.N., Pandey, A. and Nampoothiri, K.M. (2015). Characterization of an exopolysaccharide with potential health-benefit properties from a probiotic Lactobacillus plantarum RJF4. LWT - Food Science and Technology, 64(2), 1179-1186. j.lwt.2015.07.040

Efriwati, Suwanto, A., Rahayu, G. and Nuraida, L. (2013). Population Dynamics of Yeasts and Lactic Acid Bacteria (LAB) During Tempeh Production. HAYATI Journal of Biosciences, 20(2), 57-64. https://doi.org/10.4308/hjb.20.2.57

Feng, X.M., Eriksson, A.R.B. and Schnürer, J. (2005). Growth of lactic acid bacteria and Rhizopus oligosporus during barley tempeh fermentation. International Journal of Food Microbiology, 104(3), 249-256.

j.ijfoodmicro.2005.03.005

González-Ortiz, G., Pérez, J.F., Hermes, R.G., Molist, F., Jiménez-Díaz, R. and Martín-Orúe, S.M. (2014). Screening the ability of natural feed ingredients to interfere with the adherence of enterotoxigenic Escherichia coli (ETEC) K88 to the porcine intestinal mucus. British Journal of Nutrition, 111 (4), 633-642. https://doi.org/10.1017/ S0007114513003024

Kaji, A. and Saheki, T. (1975). Endo-arabinanase from Bacillus subtilis F-11. Biochimica et Biophysica Acta (BBA) - Enzymology, 410(2), 354-360. https:// doi.org/10.1016/0005-2744(75)90237-5
Keuth, S. and Bisping, B. (1994). Vitamin B12 production by Citrobacter freundii or Klebsiella pneumoniae during tempeh fermentation and proof of enterotoxin absence by PCR. Applied and Environmental Microbiology, 60(5), 1495-1499.

Kiers, J.L., Nout, M.J.R., Rombouts, F.M., Nabuurs, M.J.A. and Meulen, J.V.D. (2002). Inhibition of adhesion of enterotoxigenic Escherichia coli K88 by soya bean tempe. Letters in Applied Microbiology, 35(4), 311-315. https://doi.org/10.1046/j.1472765X.2002.01182.x

Kiers, J.L., Nout, M.J.R., Rombouts, F.M., Nabuurs, M.J.A. and Meulen, J. van der. (2007). A high molecular weight soluble fraction of tempeh protects against fluid losses in Escherichia coli-infected piglet small intestine. British Journal of Nutrition, 98 (2), 320-325. https://doi.org/10.1017/ S0007114507721463

Koeck, D.E., Pechtl, A., Zverlov, V.V. and Schwarz, W.H. (2014). Genomics of cellulolytic bacteria. Current Opinion in Biotechnology, 29, 171-183. https://doi.org/10.1016/j.copbio.2014.07.002

Kustyawati, M. (2009). Kajian Peran Yeast dalam Pembuatan Tempe. Agritech, 29(2), 64-70. https:// doi.org/10.22146/agritech.9765

Mirelman, D., Altmann, G. and Eshdat, Y. (1980). Screening of bacterial isolates for mannose-specific lectin activity by agglutination of yeasts. Journal of Clinical Microbiology, 11(4), 328-331.

Mulyowidarso, R.K., Fleet, G.H. and Buckle, K.A. (1989). The microbial ecology of soybean soaking for tempe production. International Journal of Food Microbiology, 8(1), 35-46. https:// doi.org/10.1016/0168-1605(89)90078-0

Mulyowidarso, R.K., Fleet, G.H. and Buckle, K.A. (1990). Association of bacteria with the fungal fermentation of soybean tempe. Journal of Applied Bacteriology, 68(1), 43-47. https://doi.org/10.1111/ j.1365-2672.1990.tb02546.x

Muzdalifah, D., Athaillah, Z.A., Nugrahani, W. and Devi, A.F. (2017). Colour and pH changes of tempe during extended fermentation. AIP Conference Proceedings, 1803, 020036. https:// doi.org/10.1063/1.4973163

Nagy, B. and Fekete, P.Z. (2005). Enterotoxigenic Escherichia coli in veterinary medicine. International Journal of Medical Microbiology, 295 (6), 443-454. https://doi.org/10.1016/ j.ijmm.2005.07.003

Nout, M.J.R., de Dreu, M.A., Zuurbier, A.M. and Bonants-van Laarhoven, T.M.G. (1987). Ecology of controlled soyabean acidification for tempe 
manufacture. Food Microbiology, 4(2), 165-172. https://doi.org/10.1016/0740-0020(87)90032-3

Nout, M.J.R. and Kiers, J.L. (2005). Tempe fermentation, innovation and functionality: update into the third millennium. Journal of Applied Microbiology, 98(4), 789-805. https:// doi.org/10.1111/j.1365-2672.2004.02471.x

Nurdini, A.L., Nuraida, L., Suwanto, A. and Suliantari. (2015). Microbial growth dynamics during tempe fermentation in two different home industries ProQuest. International Food Research Journal, 22 (4), 1668-1674.

Owens, J.D. (2014). Indigenous Fermented Foods of Southeast Asia. $1^{\text {st }}$ ed. Boca Raton, USA: CRC Press. https://doi.org/10.1201/b17835

Qadri, F., Svennerholm, A.-M., Faruque, A.S.G. and Sack, R.B. (2005) Enterotoxigenic Escherichia coli in Developing Countries: Epidemiology, Microbiology, Clinical Features, Treatment, and Prevention. Clinical Microbiology Reviews, 18(3), 465-483. https://doi.org/10.1128/CMR.18.3.465483.2005

Radita, R., Suwanto, A., Kurosawa, N., Wahyudi, A.T. and Rusmana, I. (2017). Metagenome analysis of tempeh production: Where did the bacterial community in tempeh come from? Malaysian Journal of Microbiology, 13(4), 280-288. https:// doi.org/10.21161/mjm.101417

Radita, R., Suwanto, A., Wahyudi, A.T. and Rusmana, I. (2018). Firmicutes is the predominant bacteria in tempeh. International Food Research Journal, 25(6), 2313-2320.

Raposo, M.P., Inácio, J.M., Mota, L.J. and Sá-Nogueira, I.D. (2004). Transcriptional Regulation of Genes Encoding Arabinan-Degrading Enzymes in Bacillus subtilis. Journal of Bacteriology, 186(5), 1287-1296. https://doi.org/10.1128/JB.186.5.1287-1296.2004

Roubos-van den Hil, P.J., Nout, M.J.R., van der Meulen, J. and Gruppen, H. (2010). Bioactivity of tempe by inhibiting adhesion of ETEC to intestinal cells, as influenced by fermentation substrates and starter pure cultures. Food Microbiology, 27(5), 638-644. https://doi.org/10.1016/j.fm.2010.02.008

Roubos-van den Hil, P.J., Schols, H.A., Nout, M.J.R., Zwietering, M.H. and Gruppen, H. (2010). First Characterization of Bioactive Components in Soybean Tempe That Protect Human and Animal Intestinal Cells against Enterotoxigenic Escherichia coli (ETEC) Infection. Journal of Agricultural and Food Chemistry, 58(13), 7649-7656. https:// doi.org/10.1021/jf101379y

Seumahu, C.A., Suwanto, A., Rusmana, I. and Solihin,
D.D. (2013). Bacterial and Fungal Communities in Tempeh as Reveal by Amplified Ribosomal Intergenic Sequence Analysis. HAYATI Journal of Biosciences, 20(2), 65-71. https://doi.org/10.4308/ hjb.20.2.65

Soka, S., Suwanto, A., Sajuthi, D. and Rusmana, I. (2014). Impact of Tempeh Supplementation on Gut Microbiota Composition in Sprague-Dawley Rats. Research Journal of Microbiology, 9(4), 189-198. https://doi.org/10.3923/jm.2014.189.198

Tamam, B., Syah, D., Suhartono, M.T., Kusuma, W.A., Tachibana, S. and Lioe, H.N. (2019). Proteomic study of bioactive peptides from tempe. Journal of Bioscience and Bioengineering, 128(2), 241-248. https://doi.org/10.1016/j.jbiosc.2019.01.019

Wang, Y., Gänzle, M.G. and Schwab, C. (2010). Exopolysaccharide Synthesized by Lactobacillus reuteri Decreases the Ability of Enterotoxigenic Escherichia coli To Bind to Porcine Erythrocytes. Applied and Environmental Microbiology, 76(14), 4863-4866. https://doi.org/10.1128/AEM.03137-09

Wang, J., Zeng, Y., Wang, S., Liu, H., Zhang, D., Zhang, W., Wang, Y. and Ji, H. (2018). Swine-Derived Probiotic Lactobacillus plantarum Inhibits Growth and Adhesion of Enterotoxigenic Escherichia coli and Mediates Host Defense. Frontiers in Microbiology, 9, 1364. https://doi.org/10.3389/ fmicb.2018.01364 